\title{
Synthesis of Modified Peptidoglycan Precursor Analogues for the Inhibition of Glycosyltransferase
}

\author{
Shrinivas Dumbre, ${ }^{\dagger}$ Adeline Derouaux, ${ }^{\ddagger}$ Eveline Lescrinier, ${ }^{\dagger}$ André Piette, ${ }^{\ddagger}$ Bernard Joris, ${ }^{\ddagger}$ \\ Mohammed Terrak, ${ }^{\ddagger}$ and Piet Herdewijn ${ }^{*} \dagger$ \\ ${ }^{\dagger}$ Laboratory of Medicinal Chemistry, Rega Institute for Medical Research, University of Leuven (KU Leuven), Minderbroedersstraat \\ 10, 3000 Leuven, Belgium \\ ${ }^{\ddagger}$ Centre d’Ingénierie des Protéines, Université de Liège, Allée de la chimie, B6a, B-4000, Sart Tilman, Liège, Belgium
}

Supporting Information

ABSTRACT: The peptidoglycan glycosyltransferases (GTs) are essential enzymes that catalyze the polymerization of glycan chains of the bacterial cell wall from lipid II and thus constitute a validated antibacterial target. Their enzymatic cavity is composed of a donor site for the growing glycan chain (where the inhibitor moenomycin binds) and an acceptor site for lipid II substrate. In order to find lead inhibitors able to fill this large active site, we have synthesized a series of substrate analogues of lipid I and lipid II with variations in the lipid, the pyrophosphate, and the peptide moieties and evaluated their biological effect on the GT activity of E. coli PBP1b and their antibacterial potential. We found several compounds able to inhibit the GT activity in vitro and cause growth defect in Bacillus subtilis. The more active was C16-phosphoglycerate-MurNAc-(L-AlaD-Glu)-GlcNAc, which also showed antibacterial activity. These molecules are promising leads for the design of new antibacterial GT inhibitors.

\section{INTRODUCTION}

The problem of multidrug resistant (MDR) bacteria is on the rise. $^{1-3}$ The difficulty of treating infections due to MDR strains causes a longer incubation time with antibiotics, during which microbial resistance is spread to others. This inflicts huge costs on health care, and potentially increases mortality and morbidity. To face this threat, new antiobiotics are urgently needed.

Bacteria have a unique cellular feature called the peptidoglycan (PG) sacculus, a polymeric layer that is the main constituent of bacterial cell walls and is absent in animal cells. ${ }^{4}$ The monomeric unit precursor of the PG consists of $\mathrm{N}$ acetylmuramic acid (MurNAc) and $N$-acetylglucosamine (GlcNAc) linked to an undecaprenyl pyrophosphate lipid carrier, and a pentapeptide (lipid II, 1, Figure 1A). This monomeric unit is assembled in the cytoplasm and then flipped out into the periplasm, ${ }^{5,6}$ where it is used as a substrate by the membrane bound glycosyltransferases (GTs) to synthesize the glycan chains (nascent PG). The growing glycan chains are cross-linked and attached to a preexisting PG sacculus via an amide bond formation between the peptide chains by transpeptidases; this reaction is the target of $\beta$-lactam antibiotics. ${ }^{7}$ Inhibition of the GT step by the specific inhibitor moenomycin leads to bacterial death. This makes the GTs a validated and attractive target for the development of new antibacterials against antibiotic multiresistant strains. Moenomycin (2, Figure 1B) is not used clinically because of its poor pharmacokinetic properties, which is related to its phosphoglycerate lipid tail. To overcome this limitation, extensive structure-activity relationship studies have been carried out on moenomycin ${ }^{8-13}$ which identified the phosphoglycerate moenocinol trisaccharide as the minimal structural feature required for antibacterial and GT inhibitory activities.

Recently the first structures of GTs and their complexes with moenomycin became available. ${ }^{14-18}$ The GT domain is composed of two lobes (head and jaw domains). The fold of the head domain shows structural similarities with that of the phage $\lambda$ lysozyme $(\lambda \mathrm{L})$. The jaw domain is specific to the GT51 family and has a hydrophobic region partly embedded in the cytoplasmic membrane to presumably facilitate the access to the membrane bound lipid II substrate. The active site of GT is located at the interface of the two lobes and can be divided into two substrate binding sites: a donor site for the growing glycan chain and where moenomycin binds, and an acceptor site for lipid II (Figure 1A).

The length of the lipid moiety is critical for the inhibitory activity of moenomycin and the processive turnover of the substrate by GT. ${ }^{19}$ For the substrate, this property is determined essentially by the donor site which requires a lipid longer than 20 carbons (maximum activity observed with betulaheptaprenyl, $\mathrm{C} 35^{20}$ ), whereas the acceptor site can accept a shorter lipid. ${ }^{19}$ Therefore the use of substrate analogues with reduced lipid chain length and targeting the acceptor site with high affinity could be a new approach in the design of active GT inhibitors. As prerequisite to this we need to better understand

Received: March 2, 2012 


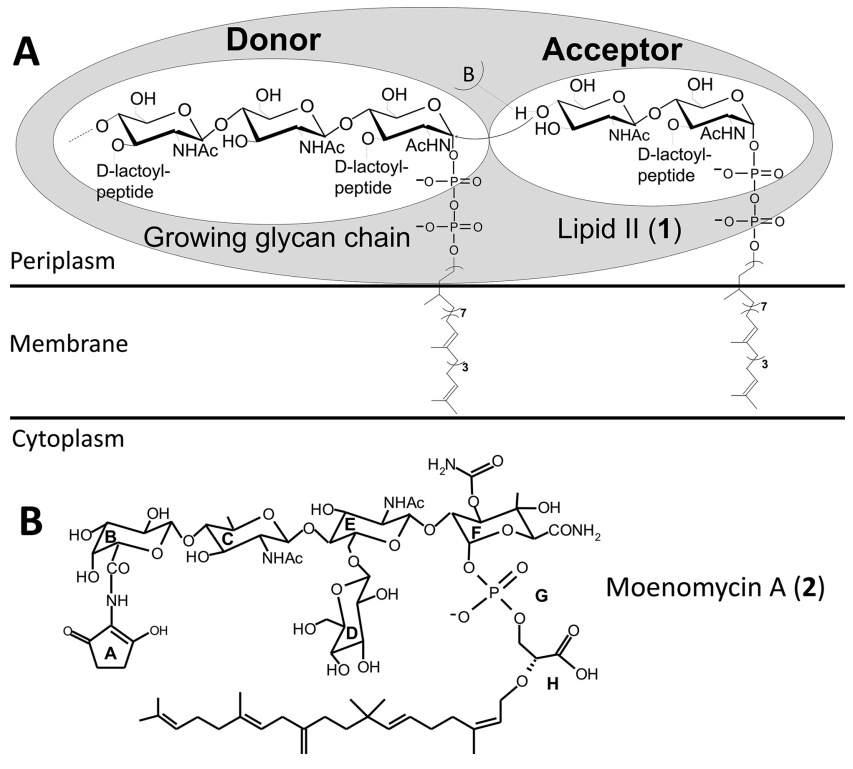

Figure 1. Membrane steps of bacterial cell wall biosynthesis and structure of the GT ligands. (A) Schematic representation of the GT domain catalyzing the glycan chain elongation. The elongating glycan chain binds to the donor site, and lipid II (1) binds to the acceptor site. Catalysis occurs by deprotonation of $4-\mathrm{OH}$ of lipid II by the catalytic glutamate (E233 in PBP1b) followed by nucleophilic attack on the $\mathrm{C} 1$ of the growing chain and departure of the undecaprenylpyrophosphate. (B) Structure of moenomycin A (2), an analogue of the growing glycan chain which binds to the donor site.

the contribution of the different moieties (lipid, pyrophosphate, sugars, and peptide) of the lipid II substrate for binding to the GT enzymatic cavity.

In early 2000, the semisynthesis and total synthesis of lipid I and lipid II substrates was reported. ${ }^{20-22}$ However, there have been limited efforts in designing and synthesizing lipid I/II based inhibitors for GT. ${ }^{23-26}$ This is probably due to the structural complexity and chemical instability of lipid I/II, which complicates the synthetic efforts of modified lipid I and lipid II.

In this work we aim to understand the substrate specificity of E. coli PBP1b and identify substrate analogues able to inhibit the GT activity of the enzyme. These analogues could be used as templates for structure-based drug design to optimize substrates for the donor site, acceptor site, or both. We have synthesized a series of substrate analogues of lipid I and lipid II with variations in the lipid, the pyrophosphate, and the peptide moieties and evaluated their biological effect on the GT activity of E. coli PBPlb and their antibacterial potential.

\section{RESULTS AND DISCUSSION}

Design and Synthesis of Lipid I and Lipid II Monophosphate Analogues. We have synthesized several lipid I and lipid II analogues, related to the structure of moenomycin, with minimal molecular fragments. Figure 2 shows the resemblance between the moenomycin EFG fragment (3, Figure 2) and lipid II (1): both have a GlcNAc residue as second sugar. The undecaprenyl pyrophosphate moiety in $\mathbf{1}$ is replaced by an isoelectronic phosphoglycerate moenocinol unit in 3 . Besides the presence of a phosphoglycerate function, the major difference between compound FG fragment (4) and lipid I is the presence of carbamoyl group on the 3-hydroxyl group (instead of lactoyl pentapeptide), a
Concept and Design

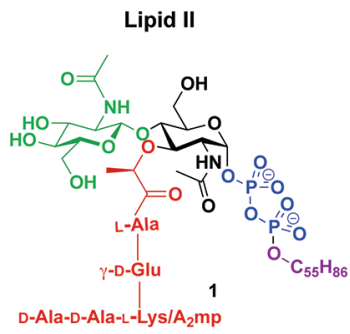

Moenomycin A (EFG fragment)

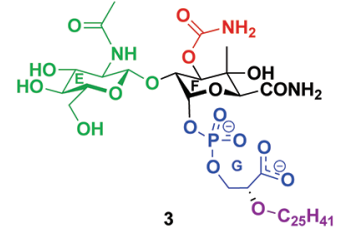

Moenomycin A (FG fragment)

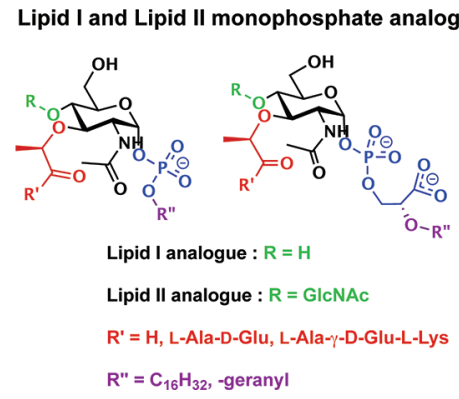

Figure 2. Concept and design. Structures of the peptidoglycan precursor lipid II (1), disaccharide fragment (EFG, 3), and monosaccharide fragment (FG, 4) of moenomycin. Structures of the lipid I and lipid II monophosphate analogues that we have synthesized (18 analogues); these compounds have three main structural features: (a) a monophosphate lipid chain, as monophosphates are less prone to hydrolysis than pyrophosphate, (b) with or without a shorter peptide unit, and (c) a phosphoglycerate as a lipid carrier, as in moenomycin which mimics the pyrophosphate.

carboxamate on position 5 (instead of hydroxymethyl group), and an hydroxyl group on position 2 (instead of the $N$-acetyl group).

We have prepared 18 analogues of lipid I/II as outlined in Figure 2. Analogues of lipid I $(17,18)$ and lipid II $(19,20$, and 21) were synthesized following the synthetic strategy shown in Scheme 3. Compound $6^{27}$ was obtained starting from $N$-acetyl glucosamine (5). The benzyl glycoside of $N$-acetyl glucosamine was acetylated, and then the benzyl group was removed by hydrogenolysis to afford 6 (Scheme 1). Compound 6 is the starting material for the synthesis of lipid I analogues $\mathbf{1 7}$ and 18. Phosphorylation of 6 by reaction with dibenzyl $N, N$ diisopropylphosphoramidite and $1 H$-tetrazole, followed by

\section{Scheme 1}

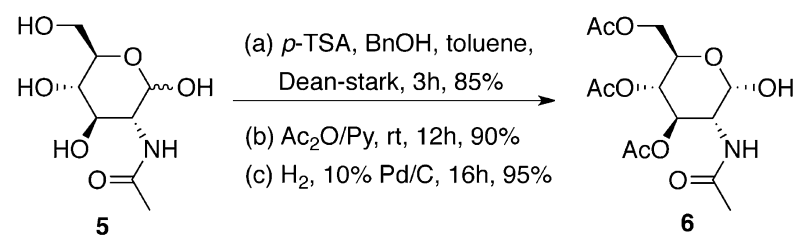

(a) $\mathrm{N}, \mathrm{N}$-diisopropylphosphoramidite, $0.5 \mathrm{~N}$ tetrazole, $\mathrm{CH}_{3} \mathrm{CN}, 3 \mathrm{~h} ; 35 \% \mathrm{H}_{2} \mathrm{O}_{2}$, THF, $-78^{\circ} \mathrm{C}, 15 \mathrm{~min}, \mathrm{rt}, 1 \mathrm{~h}, 76 \%$

(b) $\mathrm{H}_{2}, 10 \% \mathrm{Pd} / \mathrm{C}, 18 \mathrm{~h}, 80 \%$; TEA

(c) 2.1 eq, $40 \%$ aq. $n-\mathrm{Bu}_{4} \mathrm{~N}^{+} \mathrm{O}-\mathrm{H}$

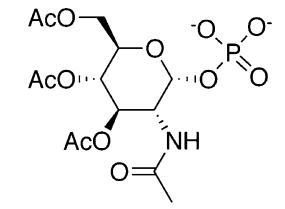

$$
\begin{array}{r}
\mathbf{6} \stackrel{a, b}{\longrightarrow} 7 \text { as TEA salt } \\
8 \text { as } n-\mathrm{Bu}_{4} \mathrm{~N}^{+}
\end{array}
$$




\section{Scheme 2}

A<smiles>N[C@H]1C(O)[C@@H](O)C(CO)O[C@@H]1O</smiles>

9 (a) $\mathrm{NaHCO}_{3} / \mathrm{H}_{2} \mathrm{O}$

$\mathrm{CCl}_{3} \mathrm{CH}_{2} \mathrm{COCl}$

$0^{\circ} \mathrm{C}$ to rt, $16 \mathrm{~h}, 95 \%$

(b) $\mathrm{Ac}_{2} \mathrm{O} / \mathrm{Py}, \mathrm{rt}$,

$12 \mathrm{~h}, 99 \%$
B<smiles>CC(=O)N[C@H]1C(O)[C@H](O)[C@@H](CO)O[C@H]1O</smiles>

12 (a) p-TSA, $\mathrm{BnOH}$, toluene, Dean-stark, 3h, $85 \%$

(b) $\mathrm{PhCHO},(\mathrm{EtO}){ }_{3} \mathrm{CH}, p$-TSA Dioxane:DMF (1:1), rt, vacuum 130-160 mbar, $3 \mathrm{~h}, 70 \%$<smiles>CC(=O)OC[C@H]1O[C@H](OC(C)=O)[C@H](NC(=O)OCC(Cl)(Cl)Cl)[C@H](OC(C)=O)[C@@H]1OC(C)=O</smiles>

10 (a) Hydrazine Acetate DMF, rt, $20 \mathrm{~min}, 94 \%$

(b) $\mathrm{Cl}_{3} \mathrm{CCN} / \mathrm{DBU}$ DCM, rt, 1 h, $78 \%$

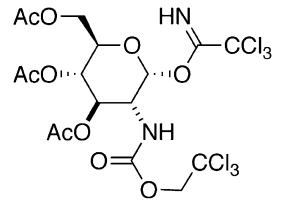

11

C

(a) TMSOTf, MS $4 \AA$, DCM, $76 \%$

(b) i) $\mathrm{ZnCl}_{2}, \mathrm{AcOH}: \mathrm{Ac}_{2} \mathrm{O}(1: 3)$;

ii) $\mathrm{Zn}$ dust, THF: $\mathrm{Ac}_{2} \mathrm{O}: \mathrm{AcOH}(3: 2: 1), 65 \%$

(c) $\mathrm{H}_{2}, 10 \% \mathrm{Pd} / \mathrm{C}, \mathrm{MeOH}, 1 \mathrm{~atm}, 95 \%$.

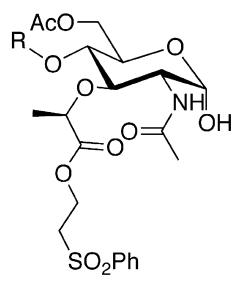

15

(a) $\mathrm{NaH}, \mathrm{L}-2$-chloropropionic acid<smiles>CC(=O)N[C@H]1C(O)[C@H]2OC(c3ccccc3)OC[C@H]2O[C@H]1Cc1ccccc1</smiles>

13 (b) $\mathrm{PhSO}_{2} \mathrm{CH}_{2} \mathrm{CH}_{2} \mathrm{OH}, \mathrm{EDCl}$,
$\mathrm{DMAP}, \mathrm{DCM}, 0^{\circ} \mathrm{C}$ to rt, $8 \mathrm{~h}, 75 \%$
(c) $\mathrm{TfOH} /$ Triethyl silane
$\mathrm{DCM},-78^{\circ} \mathrm{C}, 80 \%$

14

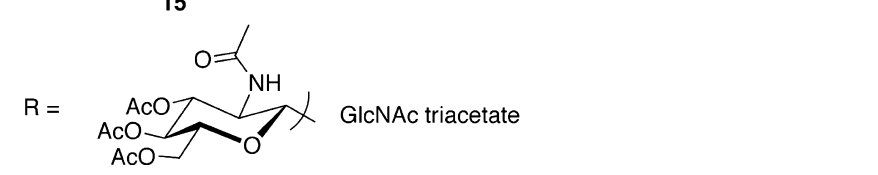

(a) dibenzyl N, N-diethylphosphoramidite, $0.5 \mathrm{~N}$ tetrazole, $3 \mathrm{~h}$, rt, $\mathrm{CH}_{3} \mathrm{CN}$; $45 \% \mathrm{H}_{2} \mathrm{O}_{2},-78^{\circ} \mathrm{C}, 15 \mathrm{~min}, \mathrm{rt}, 30 \mathrm{~min} 80 \%$

(b) $\mathrm{H}_{2}, 10 \% \mathrm{Pd} / \mathrm{C}$, THF:MeOH (4:1), 1 atm, rt, $90 \%$ (c) 2.1 eq, $40 \%$ aq n-Bu ${ }_{4} \mathrm{~N}^{+} \mathrm{O}^{-} \mathrm{H}, 100 \%$ 16

$\mathrm{R}=\mathrm{GlcNAc}$ triacetate

\section{Scheme 3}

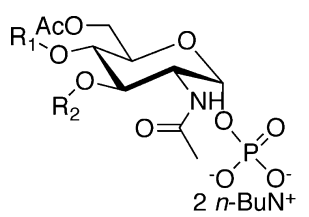

(a) prenyl bromide or farnesyl bromide or cetyl bromide, dry $\mathrm{CH}_{3} \mathrm{CN}$, rt, $18 \mathrm{~h}-36 \mathrm{~h}$ (b) $\mathrm{K}_{2} \mathrm{CO}_{3}$, acetonitrile or $\mathrm{LiOH}, \mathrm{MeOH}-\mathrm{H}_{2} \mathrm{O}$

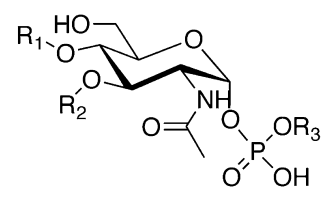

$8: R_{1}$ and $R_{2}=H$

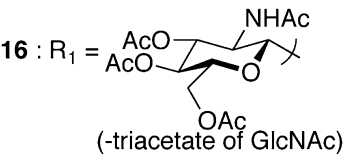<smiles>[R]C(=O)C(C)(C)C(=O)OCCS(=O)(=O)c1ccccc1</smiles>

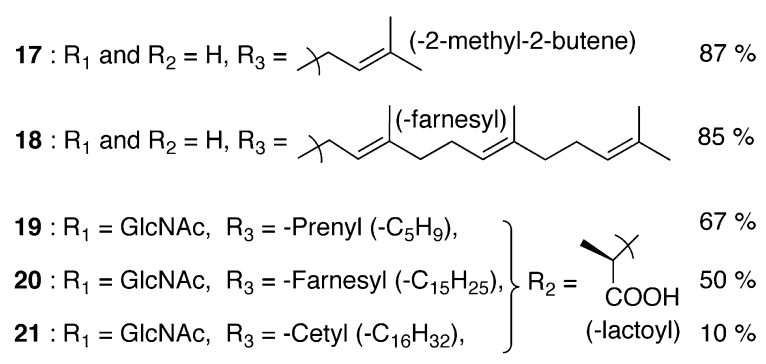

oxidation with hydrogen peroxide and debenzylation, afforded $7^{28}$ as a triethylamine salt. Compound 7, after activation with $N, N^{\prime}$-dicyclohexylcarbodiimide or tosyl chloride or 2,4,6triisopropylbenzenesulfonyl chloride ${ }^{29}$ and treatment with prenol, failed to give the desired alkylated phosphate analogue: invariably a pyrophosphate dimer was formed. Therefore, an alternative approach was considered in which the nucleophilicity of the phosphate group is enhanced by using bulky tetra- $n$ butylammonium as counterion. ${ }^{30}$ Thus compound 7 was mixed with 2.1 equiv of tetra- $n$-butylammonium hydroxide and lypholized to obtain compound $\mathbf{8}$ as a bis(tetra- $n$-butyl)ammonium salt. This salt underwent smooth alkylation of the phosphate function with prenyl bromide in the presence of $4 \AA$ molecular sieves to afford the prenylated phosphate compound, which upon deacetylation via saponification afforded 17 in $87 \%$ yield.

For the preparation of the lipid II disaccharide monophosphate prenyl analogue 19, the synthesis of the disaccharide monophosphate 16 is required. This synthesis was carried out by following a modified version of a published protocol, ${ }^{31,32}$ as illustrated in Scheme 2. This involves the synthesis of the trichloroacetimidate-activated donor (GlcNAc) 11 and acceptor (MurNAc) 14. Schmidt's glycosylation ${ }^{33}$ reaction between 11 and 14, followed by removal of the 6-O-benzyl and $\mathrm{N}$-Troc 
groups, their reprotection as acetates, and the removal of the anomeric $O$-benzyl group by hydrogenolysis, afforded the lipid II disaccharide precursor 15. Compound $\mathbf{1 5}$ was phosphorylated, debenzylated, and converted to its bis(tetra- $n$-butyl)ammonium salt (16) in analogy to the procedure described for 8. We further utilized the bis(tetra- $n$-butyl)ammonium salts 8 and 16 to obtain the farnesyl lipid I (18), the prenyl lipid II (19), the farnesyl lipid II (20), and the cetyl lipid II (21) monophosphate analogues (see Scheme 3).

The GT substrate analogues 17 and 19 bearing a prenyl chain and the compounds $\mathbf{1 8}$ and $\mathbf{2 0}$ did not show inhibition of E. coli PBP1b GT activity (data not shown). Compounds $\mathbf{1 8}$ and $\mathbf{2 0}$ have a tendency to aggregate, which may contribute to their inactivity. Compound $\mathbf{2 1}$ with a saturated C16 lipid chain shows a $K_{\mathrm{i}}$ value of $26 \pm 6 \mu \mathrm{M}$ (see the section GT Inhibition and Antibacterial Activities of Lipid I and Lipid II Analogues and Table 2). This promising initial result encouraged us to increase the molecular complexity of lipid I/II analogues by incorporating suitable peptides and phosphoglycerate saturated C16 moieties.

The Boc protected L-Ala-D-Glu (22) and L-Ala- $\gamma$-D-Glu-L-Lys (25) peptides, having base labile protecting groups in the side chains, were synthesized using standard solution phase protocols as shown in Scheme 4. The dimethyl ester

\section{Scheme 4}

A

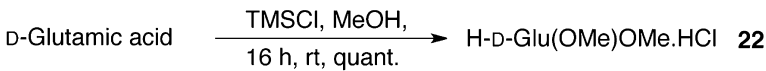

$\mathrm{N}$-methylmorpholine, EDCI, DCM

$\underset{\text { Boc-L-Ala-OH, rt, } 8 \text { h, } 78 \%}{\longrightarrow}$ Boc-L-Ala-D-Glu(OMe)OMe 23

B Boc-D-Glu-OBzl + H-L-Lys(Fmoc)OMe. $\mathrm{HCl}$

$\downarrow$ EDCI, HOBt, DCM, rt, $89 \%$

Boc- $\gamma$-D-Glu-OBzI-L-Lys(Fmoc)OMe 24

(a) $6 \mathrm{~N} \mathrm{HCl}$ in isopropanol, DCM

(b) Boc-L-Ala-OH

EDCl, HOBt, DCM, rt, $83 \%$

Boc-L-Ala- $\gamma$-D-Glu-OBzl-L-Lys(Fmoc)OMe 25

hydrochloride of D-glutamic acid (22) was obtained from Dglutamic acid with trimethylsilyl chloride in methanol ${ }^{34}$ and was coupled to Boc-L-Ala-OH under standard 1-ethyl-3-(3'dimethylaminopropyl)carbodiimide (EDCI) conditions to afford the dipeptide $\mathbf{2 3}$ in $\mathbf{7 8 \%}$ yield over two steps. Boc-DGlu-OBzl was coupled with $N^{6}$-Fmoc protected methyl ester of L-Lys to afford the dipeptide $\mathbf{2 4}$ in $89 \%$ yield. Deprotection, followed by EDCI mediated coupling with Boc-L-Ala-OH, gave the protected tripeptide $\mathbf{2 5}$ in $83 \%$ yield.

For the synthesis of phosphoglycerates, ${ }^{12,23}$ we have developed a protocol starting from D-mannitol (Scheme 5) that serves as a chiral pool for the glycerate moiety and was used to obtain acetonide protected alcohol 26 on a multigram scale. ${ }^{35}$ The $(S)$-acetonide protected glycerol 26 was subjected to $p$-methoxybenzyl (PMB) protection as it can be selectively removed under neutral conditions with 2,3-dichloro-5,6dicyanobenzoquinone (DDQ). Acetonide deprotection and regioselective protection of the primary hydroxyl group with $t$ butyldiphenylsilyl (TBDPS) gave the key intermediate 27a. This key intermediate (27a) was cetylated by treatment with
Scheme 5

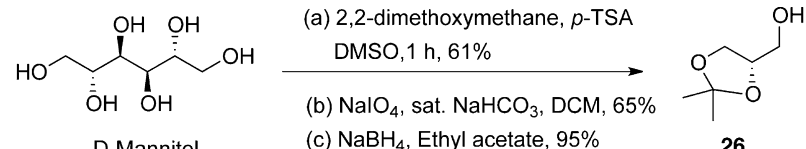

D-Mannitol

(c) $\mathrm{NaBH}_{4}$, Ethyl acetate, $95 \%$

26 (a) PMBBr, NaH, TBAI, DMF, $0{ }^{\circ} \mathrm{C}$ to $\mathrm{rt}, 4 \mathrm{~h}, 90 \%$ (b) $80 \%$ acetic acid, $70^{\circ} \mathrm{C}$, $3 \mathrm{~h}, 84 \%$.<smiles>[R5]OCC(CO[R6])O[R]</smiles>

$28: \mathrm{R}=-\mathrm{C}_{16} \mathrm{H}_{33}, 87 \%$

$29: \mathrm{R}=$ > $80 \%$ (a) $\mathrm{DDQ}, p \mathrm{H} 7,5-10^{\circ} \mathrm{C}, 3 \mathrm{~h}$

(b) PDC, DMF, rt, 12h

(c) $2 \mathrm{M} \mathrm{TMSCH} \mathrm{N}_{2}, \mathrm{MeOH}$

$30 \mathrm{~min}$

(d) TBAF, THF, 3h

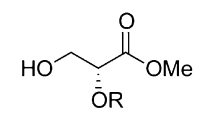

$30: \mathrm{R}=-\mathrm{C}_{16} \mathrm{H}_{33}, 47 \%$

$31:$ R = geranyl, $35 \%$

sodium hydride and cetyl bromide to afford 28 in $87 \%$ yield. It is worth noting that the initial efforts to remove the PMB group at room temperature and dichloromethane as a solvent was found to be poor yielding. However, the reaction when carried out in the presence of $\mathrm{pH} 7$ phosphate buffer at $5-10{ }^{\circ} \mathrm{C}$, followed by careful removal of DDQ-2H and work up by precipitation with diethyl ether, afforded the required product in $84 \%$ yield. This PMB deprotected compound was subsequently oxidized and methylated and TBDPS deprotection afforded the desired glycerate cetyl chain (30) in $47 \%$ yield over four steps. The glycerate geranyl compound 31 was prepared in the same way.

The alkylation strategy used to prepare $\mathbf{2 1}$ is poor, yielding $10 \%$ (Scheme 3), and the strategy does not allow peptide coupling regioselectively, as the free phosphate form will compete for the peptide coupling reaction. A new synthetic strategy was devised, which utilizes phosphoramidite chemistry for the preparation of monophosphate triester. ${ }^{36}$

Bisdiisopropyl amine chlorophosphine was treated with benzyl alcohol to obtain benzyl diisopropylamine phosphoramidite. ${ }^{37}$ This phosphoramidite reagent was used to prepare the phosphoramidite 33 and the phosphoglycerate 34 (Scheme 6). For the preparation of lipid I monophosphate analogues bearing a peptide moeity, MurNAc sugar 37 was obtained from compound 13b (Scheme 7). Acid mediated benzylidene acetal removal and reprotection of the two hydroxyl functionalities with acetates followed by hydrogenolysis of the anomeric

\section{Scheme 6}

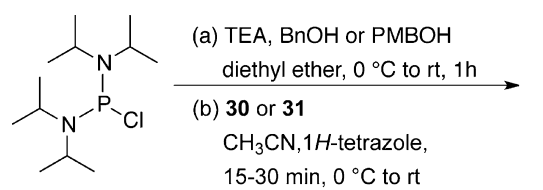

32

(a) TEA, $\mathrm{BnOH}$, diethyl ether, $1 \mathrm{H}$-tetrazole, 15 min, $0{ }^{\circ} \mathrm{C}$ to rt 
Scheme 7<smiles>CC(=O)N[C@H]1C(OC(C)C(=O)OCCS(=O)(=O)c2ccccc2)O[C@@H](OCc2ccccc2)C2COC(c3ccccc3)OC21</smiles>

13b (a) $80 \% \mathrm{AcOH}, 60^{\circ} \mathrm{C}, 2 \mathrm{~h}, 80 \%$

(b) $\mathrm{Ac}_{2} \mathrm{O}, \mathrm{Py}, 3 \mathrm{~h}, \mathrm{rt}, 85 \%$

(c) $\mathrm{Pd} / \mathrm{C}, \mathrm{H}_{2} 1 \mathrm{~atm}, \mathrm{CH}_{3} \mathrm{OH}, 5 \mathrm{~h}, 98 \%$

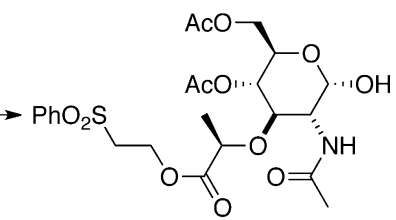

37

\section{Scheme 8}

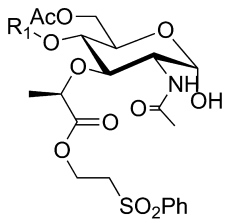

$37: \mathrm{R}_{1}=\mathrm{H}$

$15: R_{1}=$ GIcNAc triacetate

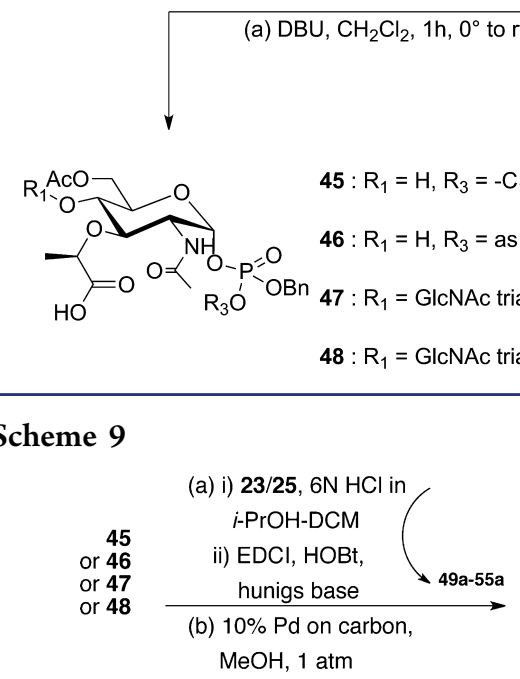
(a) (a) i) 33 or $34,1 \mathrm{H}$-tetrazole, $\mathrm{CH}_{3} \mathrm{CN} / \mathrm{CH}_{2} \mathrm{Cl}_{2}$, $8 \mathrm{~h}$ to $16 \mathrm{~h}$; ii) $\mathrm{H}_{2} \mathrm{O}_{2},-78^{\circ} \mathrm{C} 5 \mathrm{~min}, 30 \mathrm{~min} \mathrm{rt}$, or $0.5 \mathrm{MI}_{2}$ in THF-py<smiles>CCC</smiles>

$42: R_{1}=H, R_{3}=-C_{16} H_{32}, 65 \%$

$43: \mathrm{R}_{1}=\mathrm{H}, \mathrm{R}_{3}=\underbrace{\mathrm{O}_{\mathrm{OH}}}_{\mathrm{O}\left(\mathrm{CH}_{2}\right)_{15} \mathrm{CH}_{3}} 90 \%$

$21: \mathrm{R}_{1}=\mathrm{GlCNAC}, \mathrm{R}_{3}=-\left(\mathrm{CH}_{2}\right)_{15} \mathrm{CH}_{3}, 40 \%$

$44: R_{1}=$ GIcNAc, $R_{3}=$ as in $\mathbf{4 3}, 88 \%$

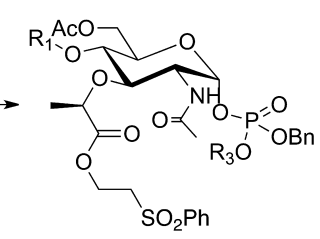

(a) $\mathrm{Pd} / \mathrm{C}, \mathrm{H}_{2}, 1 \mathrm{~atm}$

(b) $\mathrm{LiOH}, \mathrm{CH}_{3} \mathrm{CN}-\mathrm{MeOH}-\mathrm{H}_{2} \mathrm{O}$ Flash chromatography or BioGel-P2 purification
$40: \mathrm{R}_{1}=\mathrm{GICNAc}$ triacetate, $\mathrm{R}_{3}=-\left(\mathrm{CH}_{2}\right)_{15} \mathrm{CH}_{3}, 81 \%$

$41: R_{1}=$ GlcNAc triacetate, $R_{3}=$ as in $\mathbf{3 9}, 53 \%$

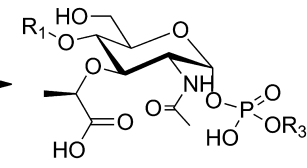

$38: R_{1}=H, R_{3}=-C_{16} H_{33}, 78 \%$

$39: \mathrm{R}_{1}=\mathrm{H}, \mathrm{R}_{3}=\underbrace{\mathrm{O}}_{\substack{\mathrm{O}\left(\mathrm{CH}_{2}\right)_{15} \mathrm{CH}_{3} \\ \mathrm{~N}_{\mathrm{OMe}}}} 66 \%$
(1) 
Scheme 10

\author{
(a) 2-chloro-4H-1,3,2-benzodioxaphosphorin-4-one \\ TEA, dry acetonitile, $0^{\circ} \mathrm{C}, 30 \mathrm{~min}, \mathrm{H}_{2} \mathrm{O}$ \\ (b) i) 31, molecule seives, dry pyridine, \\ adamantanecarbonyl chloride, $2 \mathrm{~h}$, $\mathrm{rt}$ then \\ $\mathrm{NMM}, \mathrm{CCl}_{4}, \mathrm{H}_{2} \mathrm{O}$, Acetonitrile \\ ii) $\mathrm{DBU}, \mathrm{DCM}, \mathrm{rt}$ \\ (c) $\mathrm{LiOH}, \mathrm{CH}_{3} \mathrm{CN}-\mathrm{MeOH}-\mathrm{H}_{2} \mathrm{O}$, rt
}

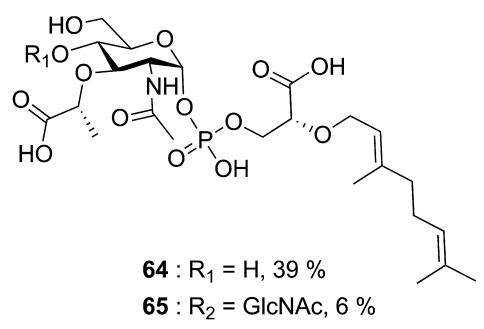

followed by mild oxidation in the presence of $\mathrm{N}$-methylmorpholine (NMM) $-\mathrm{CCl}_{4}$ and careful saponification, gave the desired analogue 64. In a similar way, the disaccharide monophosphate geranyl glycerate analogue 65 was obtained from 15.

GT Inhibition and Antibacterial Activities of Lipid I and Lipid II Analogues. Monophosphate Analogues. Monophosphate analogues of lipid I and lipid II carrying a saturated 16 carbon lipid chain without peptide stems or having a dipeptide or tripeptide (Schemes 8 and 9; 42, 21, 56, 57, 58, 59, and 60) have been evaluated for the inhibition of the GT activity and antibacterial effect. They were all able to inhibit the GT activity of PBP1b in vitro to some extent (residual activities between 7 and $84 \%$ at $500 \mu \mathrm{M}$ compound). The disaccharide analogues $(21,57)$ are about 2 -fold better inhibitors than their cognate monosaccharide forms $(42,56)$, and the inhibition of GT activity by lipid I and lipid II analogues was found to decrease in a similar manner as the length of the peptide

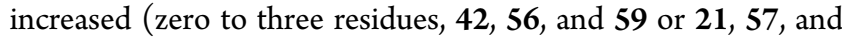
60; Table 2). The inhibitory activity of the mono- or disaccharide C16-phosphate without peptide was about 6- or 2.5-fold higher than that with tripeptide and dipeptide,

Table 2. Peptidoglycan Glycosyltransferase Inhibition and Antibacterial Activities of the Peptidoglycan Precursor Analogues $^{a}$

\begin{tabular}{cclcc} 
compd & RA $(\%)$ & \multicolumn{1}{c}{$K_{\mathrm{i}}(\mu \mathrm{M})$} & $\mathrm{MIC}(\mu \mathrm{g} / \mathrm{mL})$ & cell shape \\
$\mathbf{4 2}$ & 14 & $51.5 \pm 10.5$ & $>128$ & $\mathrm{C}$ \\
$\mathbf{5 6}$ & 43 & nd & $>128$ & $\mathrm{~N}$ \\
$\mathbf{5 8}$ & 41 & nd & $>128$ & $\mathrm{~N}$ \\
$\mathbf{5 9}$ & 84 & nd & $>128$ & $\mathrm{~N}$ \\
$\mathbf{4 3}$ & 3.5 & $21 \pm 9$ & $>128$ & $\mathrm{C}$ \\
$\mathbf{6 1}$ & 15 & $46 \pm 7.5$ & $>128$ & $\mathrm{~N}$ \\
$\mathbf{2 1}$ & 7 & $26 \pm 6$ & $>128$ & $\mathrm{C}$ \\
$\mathbf{5 7}$ & 16 & $48 \pm 11$ & $>128$ & $\mathrm{C}$ \\
$\mathbf{6 0}$ & 40 & nd & $>128$ & $\mathrm{~N}$ \\
$\mathbf{4 4}$ & 2.3 & $32.7 \pm 5$ & $>128$ & $\mathrm{C}$ \\
$\mathbf{6 2}$ & 1.7 & $17.6 \pm 2$ & 128 & $\mathrm{~L}$ \\
$\mathbf{6 3}$ & 6.5 & $36 \pm 8$ & $>128$ & $\mathrm{~N}$ \\
$\mathbf{6 4}$ & 102 & nd & $>128$ & nd \\
$\mathbf{6 5}$ & 89 & nd & $>128$ & nd
\end{tabular}

${ }^{a} \mathrm{GT}$ inhibition assays were performed with $E$. coli PBP1b. RA $=\mathrm{GT}$ residual activity of $\mathrm{PBP} 1 \mathrm{~b}$ at $500 \mu \mathrm{M}$ compounds. The data represent mean values of three independent experiments. Standard deviations were within $\pm 10 \%$ of these mean values (RA). Minimum inhibitory concentration (MIC) values and cell shapes are for B. subtilis 168. Cell shapes: C, chaining cells; N, normal cells; L, cell Lysis. nd, not determined. Similar MIC values were obtained with $S$. aureus ATCC 25923. The MIC value of moenomycin disaccharide EF was $>100 \mu \mathrm{g} /$ $\mathrm{mL}$ against several Gram-positive bacteria and $\mathrm{IC}_{50} 0.24 \mu \mathrm{M}$ using $E$. coli membrane. ${ }^{40}$ 

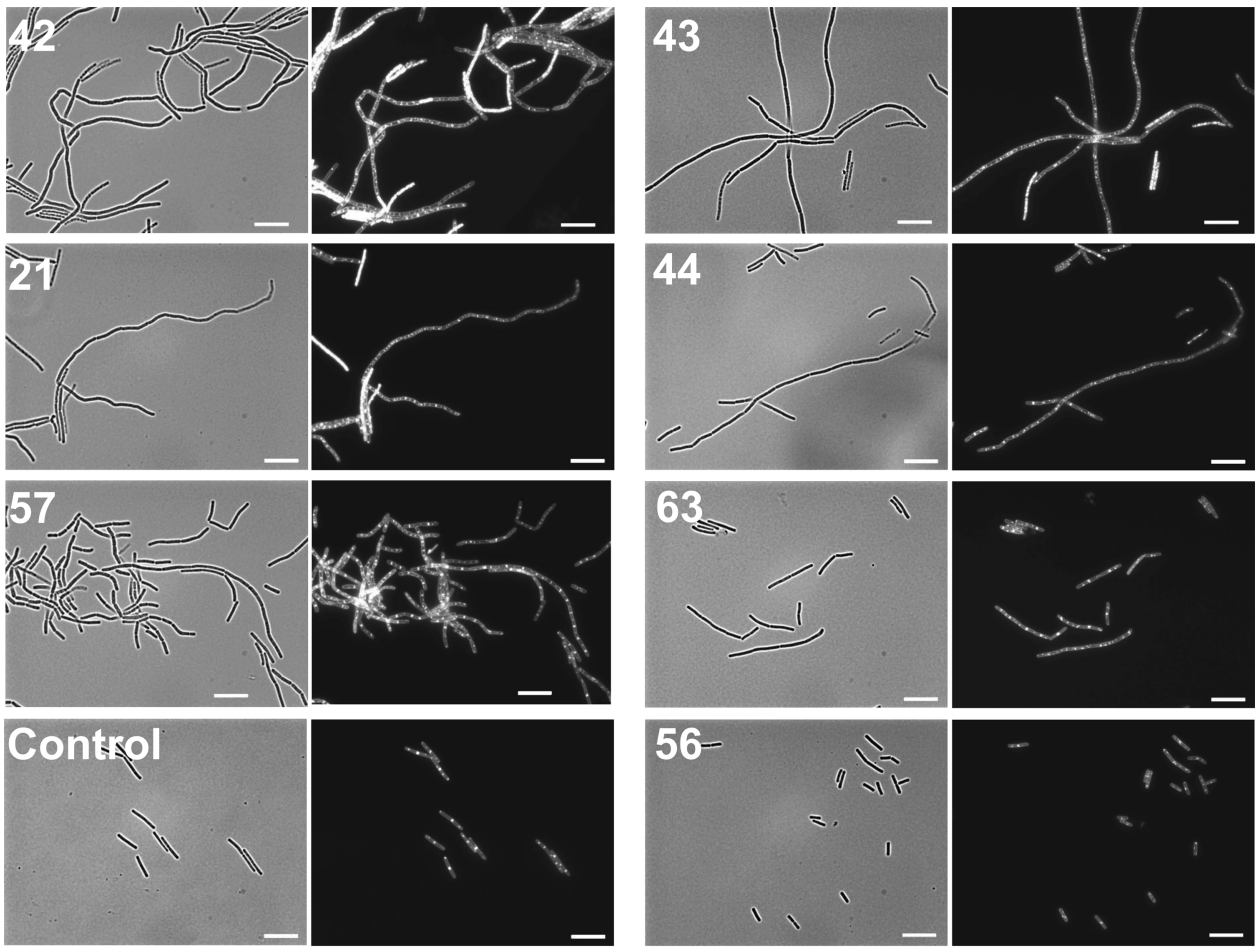

Bars, $10 \mu \mathrm{M}$

Figure 3. Cellular effect of the compounds. The cells $\left(\mathrm{OD}_{600 \mathrm{~nm}}=0.1-0.2\right)$ were incubated with $256 \mu \mathrm{g} / \mathrm{mL}$ compounds and the samples were taken at $1 \mathrm{~h}$ interval over $3 \mathrm{~h}$ and stained with the membrane dye FM-1-43-FX. The images show the effect of the compounds indicated by their code number after $3 \mathrm{~h}$ on $B$. subtilis cells observed by using both phase contrast and fluorescence microscopy.

respectively. These results show that GlcNAc plays a significant role in binding to the enzyme and that in contrast the di- or tripeptide has a negative effect. Note that the monosaccharide dipeptide with amidated glutamate $(\mathbf{5 8})$ behaves as the free carboxyl form (56).

In terms of antibacterial activity, all the compounds (monoand disaccharide C16-phosphate with or without peptide) showed MIC values higher than $128 \mu \mathrm{g} / \mathrm{mL}$ against Staphylococcus aureus ATCC 25923 and Bacillus subtilis 168 (Table $2)$. This activity is comparable to the MIC value $(>100 \mu \mathrm{g} / \mathrm{mL})$ of moenomycin disaccharide EFG derivative (close analogue of compound 21, Figure 2 and Scheme 8) for Gram-positive bacteria tested ${ }^{40}$ despite the presence of a C16-phosphate lipid tail in compound $\mathbf{2 1}$ instead of C25-phosphoglycerate in moenomycin which is known to a play important role in its activity. Surprisingly, observation of the B. subtilis cells in the microscope after $16-18 \mathrm{~h}$ of incubation with compounds shows that the most active compounds (42, 21, and 57) induced cell chaining (Figure 3). Dead cells and curved filament have been also observed in some cases. The monosaccharide dipeptide (56) and monosaccharide tripeptide (59) (the less active) do not have any effect on cell morphology. In contrast, the cells treated with the disaccharide dipeptide (57) grow as long filaments of unseparated cells, while the disaccharide tripeptide $(60)$ had no effect.

Membrane labeling of the cells with the fluorescent dye FM1-43-FX shows that most of the cells are in an advanced stage of cytokinesis but remained attached to each other by their poles. Bright fluorescent spots and probably uncompleted septa have been also observed (Figure 3). These observations show that cell division is perturbed and that cell separation is blocked by these compounds. The compounds have been also tested against E. coli and have no effect, probably because of the outer membrane barrier (data not shown).

Phosphoglycerate Analogues. The structures of E. coli PBP1b and other GTs in complexes with moenomycin show that the EF ring phosphoglycerate portion makes the major interactions with the active site residues of the GT domain. ${ }^{17} \mathrm{It}$ is believed that the phosphoglycerate moiety of moenomycin could mimic the pyrophosphate group of the substrate. In order to improve the inhibitory activity of our compounds, we have prepared a new series of compounds with C16-phosphoglycerate (Schemes 9 and 10) as a C-1 substituent.

The biological evaluation shows that all phosphoglycerate compounds (43, 44, 61, 62, and 63) had increased inhibitory activity of the GT (3-10-fold approximately) compared to their cognate monophosphate analogues (Table 2). Interestingly, the disaccharide dipeptide C16-phosphoglycerate (62) was about 2 -fold more active than the peptide-free disaccharide C16-phosphoglycertae $\left(44, K_{\mathrm{i}}=17.6\right.$ vs $\left.32.7 \mu \mathrm{M}\right)$ in contrast to the monophosphate forms where the peptide-free compound was more active. On the other hand, the antibacterial activity of all the compounds has virtually not changed (MIC > $128 \mu \mathrm{g}$ / $\mathrm{mL}$ ) except that of the disaccharide dipeptide (62), which has a MIC value of $128 \mu \mathrm{g} / \mathrm{mL}$ in accordance with the in vitro activity of this compound. This result was further confirmed by looking at the cells under the microscope; the disaccharide dipeptide did not induce cell chaining but instead provoked cell lysis at 1-2 times the MIC (data not shown). The disaccharide tripeptide (63) had a minor or no effect on cell morphology, while the disaccharide phosphoglycerate without peptide (44) induced cell chaining (Figure 3). For the monosaccharide C16phosphoglycerate compounds only the one without peptide 
(43) produced long cell chains while the dipeptide (61) form had a minor or no effect.

Overall, the data show a nice correlation between GT inhibition activity of a compound and its effect on bacterial cells, indicating that these morphological defects are due to GT inhibition.

In addition to $\mathrm{C} 16$ analogues, two phosphoglycerate geranyl substituted compounds, a monosaccharide and a disaccharide without peptide $(64,65)$, have been prepared and compared with their cognate monophosphate $C 16$ analogues (42, 21; Table 2). Interestingly, the disaccharide phosphoglycerate geranyl exhibits weak activity $(11 \%$ of inhibition at $500 \mu \mathrm{M})$ while the geranyl monophosphate was completely inactive. This suggests that the phosphoglycerate improves binding by mimicking the pyrophosphate but that the length/substitution of the lipid is a more determinant factor.

Inactivation of all GTs (four class A PBPs) in B. subtilis was not lethal, and since the mutant was still able to produce peptidoglycan and does not have a monofunctional GT, it has been proposed that $B$. subtilis contains an unknown GT different in sequence from the GT51 family. ${ }^{41}$ PG synthesis by the quadruple mutant was demonstrated in vitro and was shown to be sensitive to moenomycin, confirming the GT reaction as an antibacterial target.

Interestingly, the quadruple mutant cells have been shown to be filamentous and bent with irregularly spaced and uncompleted septa visualized by membrane staining and fluorescence microscopy. Similarly, the exposure of the wildtype strain to moenomycin resulted in a phenotype similar to that of the quadruple mutant. The similarities between our results and those of $\mathrm{McPherson}$ and Popham ${ }^{41}$ support the conclusion that the cellular defects we observed are the result of the GT inhibition. In the meantime we cannot exclude that, in addition to the GTs, these compounds also inhibit other enzymes of the peptidoglycan metabolism.

\section{CONCLUDING REMARKS}

A systematic investigation of a GT enzyme inhibition by peptidoglycan precursor analogues with variations in the carbohydrate, lipid, pyrophosphate, and peptide moieties showed that saturated $\mathrm{C} 16$ phosphoglycerate linked to MurNAc-GlcNAc (44) and to the disaccharide dipeptide (LAla-D-Glu) (62) are good inhibitors of the GT activity in vitro and are able to induce growth defects or lysis of bacterial cells. The antibacterial activities observed with the precursor analogues in this work correlate with those of the inactivation of the GT or their inhibition by moenomycin in B. subtilis ${ }^{41}$ and suggest that these compounds inhibit the GT activity in vivo. The disaccharide compounds (44 and 62) are lipid II substrate mimics and are expected to bind to both donor and acceptor sites of GT. They would have binding similar to that of the enzyme as natural substrates with the peptide (in compound 62) pointing away from the active site. ${ }^{15}$ During the initiation of a glycan chain elongation by the GT, lipid II binds to both the donor and acceptor sites; subsequently, during the elongation phase and due to the processivity of the enzyme, chain elongation occurs in the donor site by successive additions of a disaccharide unit from the acceptor site bound lipid II. Therefore, the analogue compounds have to compete with lipid II for binding to the donor site and acceptor site at the initiation phase, and then during the elongation phase the compounds have to compete also with the elongating chain. This shows the complexity of the system and will require more investigation to understand the exact mode of action of these compounds including the determination of the crystal structures of their complexes with a GT.

This will provide a good template for structure-based design of new GT inhibitors that encompass the extended polar sugar binding sites of the enzyme cavity. The affinity of such compounds for the enzyme could be further improved by bridging the donor and acceptor sites with sugar ligands with increased complexity, which could compensate for the loss or reduction of the lipid chain length, thus circumventing the negative properties of the long lipid chain observed for moenomycin.

\section{MATERIALS AND METHODS}

Reagents and Protein. Radiolabeled $\left[{ }^{14} \mathrm{C}\right.$-D-Ala $]$-lipid II $(0.078$ $\left.\mu \mathrm{Ci} \mathrm{nmol}^{-1}\right), \quad[N$-acetylglucosaminyl- $N$-acetylmuramoyl (L-Ala- $\gamma$-DGlu-(L)-meso-A2pm-(L)-D-Ala-D-Ala)-pyrophosphate-undecaprenol] meso-diaminopimelic acid, meso-A2pm, was prepared essentially as previously described in ref 42 . All compounds were solubilized in dimethyl sulfoxide (DMSO; 5-10 mM). Escherichia coli PBP1b was produced and purified as described in ref 43.

In Vitro Glycosyltransferase Activity and Inhibition Assays. In vitro peptidoglycan polymerization assay was performed by incubation of $2.5 \mu \mathrm{M} \mathrm{D}$ - $\left[{ }^{14} \mathrm{C}\right] \mathrm{Ala}-\mathrm{D}-\left[{ }^{14} \mathrm{C}\right]$ Ala-labeled lipid II $(0.078$ $\left.\mu \mathrm{Ci} \mathrm{nmol}{ }^{-1}\right)$ and purified PBPlb enzyme $(100 \mathrm{nM})$ at $30{ }^{\circ} \mathrm{C}$ in 50 $\mathrm{mM}$ Tris $\cdot \mathrm{HCl}, \mathrm{pH} 7.5,200 \mathrm{mM} \mathrm{NaCl}, 0.2 \%$ decylPEG, $10 \mathrm{mM} \mathrm{CaCl}$, and 20\% DMSO. The reactions were stopped after $7 \mathrm{~min}$ with moenomycin $(10 \mu \mathrm{M})$, and the products (unused lipid II substrate and polymerized peptidoglycan) were separated by TLC on silica gel plates (Fluka) using 2-propanol/ammonium hydroxide/water (6:3:1; v/v/v) as a mobile phase. ${ }^{44}$ Lipid II moves with the solvent $\left(R_{f}=0.65\right)$, and all the polymerized material remains at the origin in one spot $\left(R_{f}=0\right)$. The TLC plates were exposed to a storage phosphor screen (GE Healthcare) for $16 \mathrm{~h}$. The images were revealed using a Typhoon Trio + imager and analyzed using the ImageQuant TL software (GE Healthcare).

The initial GT inhibition assay was carried out by measuring the residual activity (RA) of E. coli PBP1b in the presence of $500 \mu \mathrm{M}$ compounds. All assays were repeated at least three times. The $\mathrm{IC}_{50}$ values were determined when the RAs were $<20 \%$ at $500 \mu \mathrm{M}$ compounds. Using variable concentrations of inhibitor $(0-500 \mu \mathrm{M})$, the concentration that caused $50 \%$ of reduction in the RA of an enzyme was considered as $\mathrm{IC}_{50} . K_{\mathrm{i}}$ values were determined using the equation $\mathrm{IC}_{50}=K_{\mathrm{i}}\left(1+[\mathrm{s}] / K_{\mathrm{m}}\right)$ and a $K_{\mathrm{m}}$ value of $1.8 \mu \mathrm{M}^{42}$

MIC Determination and Microscopy. Minimum inhibitory concentration (MIC) determinations were performed by the broth microdilution method against S. aureus ATCC 25923 and B. subtilis 168 according to the EUCAST (European Committee on Antimicrobial Susceptibility Testing)/CLSI (Clinical and Laboratory Standard Institute) recommended procedures. The compounds were solubilized in $100 \%$ DMSO at a concentration of $5-10 \mathrm{mg} / \mathrm{mL}$, and diluted in Mueller-Hinton broth (MHB), just before utilization.

Cells from the samples used for MIC determination were fixed on glass slabs coated with $1 \%$ agarose and examined in the microscope. ${ }^{45,46}$ This experiment was repeated by incubation of new cultured cells $\left(\mathrm{DO}_{600 \mathrm{~nm}}=0.1-0.2\right)$ with $256 \mu \mathrm{g} / \mathrm{mL}$ compounds, and the samples were taken at $1 \mathrm{~h}$ interval over $3 \mathrm{~h}$ and incubated with the fluorescent dye FM-1-43-FX (Invitrogen) to label the membranes. The cells were then fixed with formaldehyde and glutaraldehyde, washed with PBS, and observed under a fluorescent microscope (Zeiss Axio Imager.Z1). Photographs were taken with a cooled AxioCam MRm (Zeiss) mounted on the fluorescent microscope through an EC PlanNeofluar $100 \times 1.3$ oil immersion objective in bright field and fluorescence using a filter set 37 (425-475-nm band-pass excitation and 485-535-nm band-pass emission; Zeiss). Images were analyzed using the AxioVision Rel. 4.5 (Zeiss) software as previously described. ${ }^{46}$ 


\section{ASSOCIATED CONTENT}

\section{S Supporting Information}

Experimental procedures and characterization data for all new compounds used in this study. This material is available free of charge via the Internet at http://pubs.acs.org.

\section{AUTHOR INFORMATION}

\section{Corresponding Author}

Piet.Herdewijn@rega.kuleuven.be

\section{Notes}

The authors declare no competing financial interest.

\section{ACKNOWLEDGMENTS}

This work was supported by the IAP 6/19 project, and the Fonds de la Recherche Fondamentale Collective (FRFC Nos. 2.4506.08 and 2.4543.12). M.T. is a Research Associate of the National Fund for Scientific Research (F.R.S_FNRS, Belgium). We thank Martine Nguyen-Distèche for helpful discussion and Marie Schloesser for technical assistance. We thank Prof. Jef Rozenski for mass spectrometric analysis and Luc Kerremans for technical assistance. Mass spectrometry was made possible by the support of the Hercules Foundation of the Flemish Government (Grant 20100225-7).

\section{REFERENCES}

(1) Levy, S. B.; Marshall, B. Nat. Med. 2004, 10, S122.

(2) WHO, World Health Organization. Antimicrobial Resistance [Online]. 2011.http://www.who.int/mediacentre/factsheets/fs194/ en/index.html, No. 194.

(3) Zhang, Q.; Lambert, G.; Liao, D.; Kim, H.; Robin, K.; Tung, C. K.; Pourmand, N.; Austin, R. H. Science 2011, 333, 1764.

(4) Vollmer, W.; Blanot, D.; de Pedro, M. A. FEMS Microbiol. Rev. 2008, 32, 149.

(5) Mohammadi, T.; van Dam, V.; Sijbrandi, R.; Vernet, T.; Zapun, A.; Bouhss, A.; Diepeveen-de Bruin, M.; Nguyen-Disteche, M.; de Kruiiff, B.; Breukink, E. EMBO J. 2011, 30, 1425.

(6) Bouhss, A.; Trunkfield, A. E.; Bugg, T. D.; Mengin-Lecreulx, D. FEMS Microbiol. Rev. 2008, 32, 208.

(7) Sauvage, E.; Kerff, F.; Terrak, M.; Ayala, J. A.; Charlier, P. FEMS Microbiol. Rev. 2008, 32, 234.

(8) Fuse, S.; Tsukamoto, H.; Yuan, Y.; Wang, T. S.; Zhang, Y.; Bolla, M.; Walker, S.; Sliz, P.; Kahne, D. ACS Chem. Biol. 2010, 5, 701.

(9) Ostash, B.; Walker, S. Nat. Prod. Rep. 2010, 27, 1594.

(10) Welzel, P. Chem. Rev. 2005, 105, 4610.

(11) Ritzeler, O.; Hennig, L.; Findeisen, M.; Welzel, P.; Müller, D. Tetrahedron 1997, 53, 1665.

(12) Kahne, D. E.; Adachi, M.; Zhang, Y.; Leimkuhler, C.; Sun, B. Y.; LaTour, J. V. J. Am. Chem. Soc. 2006, 128, 14012.

(13) Sofia, M. J.; Allanson, N.; Hatzenbuhler, N. T.; Jain, R.; Kakarla, R.; Kogan, N.; Liang, R.; Liu, D. S.; Silva, D. J.; Wang, H. M.; Gange, D.; Anderson, J.; Chen, A.; Chi, F.; Dulina, R.; Huang, B. W.; Kamau, M.; Wang, C. W.; Baizman, E.; Branstrom, A.; Bristol, N.; Goldman, R.; Han, K. H.; Longley, C.; Midha, S.; Axelrod, H. R. J. Med. Chem. 1999, 42, 3193.

(14) Lovering, A. L.; de Castro, L. H.; Lim, D.; Strynadka, N. C. Science 2007, 315, 1402.

(15) Lovering, A. L.; Gretes, M.; Strynadka, N. C. Curr. Opin. Struct. Biol. 2008, 18, 534.

(16) Heaslet, H.; Shaw, B.; Mistry, A.; Miller, A. A. J. Struct. Biol. 2009, 167, 129.

(17) Wong, C. H.; Sung, M. T.; Lai, Y. T.; Huang, C. Y.; Chou, L. Y.; Shih, H. W.; Cheng, W. C.; Ma, C. Proc. Natl. Acad. Sci. U.S.A. 2009, 106,8824

(18) Yuan, Y.; Barrett, D.; Zhang, Y.; Kahne, D.; Sliz, P.; Walker, S. Proc. Natl. Acad. Sci. U.S.A. 2007, 104, 5348.
(19) Perlstein, D. L.; Andrew Wang, T.-S.; Doud, E. H.; Kahne, D.; Walker, S. J. Am. Chem. Soc. 2010, 132, 48.

(20) Ye, X. Y.; Lo, M. C.; Brunner, L.; Walker, D.; Kahne, D.; Walker, S. J. Am. Chem. Soc. 2001, 123, 3155.

(21) VanNieuwenhze, M. S.; Mauldin, S. C.; Zia-Ebrahimi, M.; Aikins, J. A.; Blaszczak, L. C. J. Am. Chem. Soc. 2001, 123, 6983.

(22) VanNieuwenhze, M. S.; Mauldin, S. C.; Zia-Ebrahimi, M.; Winger, B. E.; Hornback, W. J.; Saha, S. L.; Aikins, J. A.; Blaszczak, L. C. J. Am. Chem. Soc. 2002, 124, 3656.

(23) Hecker, S. J.; Minich, M. L.; Lackey, K. J. Org. Chem. 1990, 55, 4904.

(24) Qiao, L.; Vederas, J. C. J. Org. Chem. 1993, 58, 3480.

(25) Cudic, P.; Behenna, D. C.; Yu, M. K.; Kruger, R. G.; Szewczuk,

L. M.; McCafferty, D. G. Bioorg. Med. Chem. Lett. 2001, 11, 3107.

(26) Garneau, S.; Qiao, L.; Chen, L.; Walker, S.; Vederas, J. C. Bioorg. Med. Chem. 2004, 12, 6473.

(27) Mohan, H.; Vasella, A. Helv. Chim. Acta 2000, 83, 114.

(28) Heidlas, J. E.; Lees, W. J.; Pale, P.; Whitesides, G. M. J. Org. Chem. 1992, 57, 146.

(29) Itakura, K.; Katagiri, N.; Bahl, C. P.; Wightman, R. H.; Narang, S. A. J. Am. Chem. Soc. 1975, 97, 7327.

(30) Davisson, V. J.; Woodside, A. B.; Neal, T. R.; Stremler, K. E.; Muehlbacher, M.; Poulter, C. D. J. Org. Chem. 1986, 51, 4768.

(31) Lioux, T.; Busson, R.; Rozenski, J.; Nguyen-Disteche, M.; Frere, J. M.; Herdewijn, P. Collect. Czech. Chem. Commun. 2005, 70, 1615.

(32) Fraipont, C.; Sapunaric, F.; Zervosen, A.; Auger, G.; Devreese, B.; Lioux, T.; Blanot, D.; Mengin-Lecreulx, D.; Herdewijn, P.; Van Beeumen, J.; Frere, J. M.; Nguyen-Disteche, M. Biochemistry 2006, 45, 4007.

(33) Schmidt, R. R.; Michel, J. Angew. Chem., Int. Ed. Engl. 1980, 19, 731.

(34) Li, J. B.; Sha, Y. W. Molecules 2008, 13, 1111.

(35) Thomas, B. N.; Lindemann, C. M.; Corcoran, R. C.; Cotant, C. L.; Kirsch, J. E.; Persichini, P. J. J. Am. Chem. Soc. 2002, 124, 1227.

(36) Michalski, J.; Dabkowski, W. Top. Curr. Chem. 2004, 232, 93.

(37) Dreef-Tromp, C. M.; Lefeber, A. W. M.; van der Marel, G. A.; van Boom, J. H. Synthesis 1992, 1992, 1269.

(38) Stawinski, J.; Ströberg, R. Oligonucleotide Synthesis. Methods and Applications; Herdewijn, P., Ed.; Methods in Molecular Biology 288; Humana Press: Totowa, NJ, USA, 2005; p 81.

(39) Andrus, A.; Efcavitch, J. W.; McBride, L. J.; Giusti, B. Tetrahedron Lett. 1988, 29, 861.

(40) Goldman, R. C.; Baizman, E. R.; Branstrom, A. A.; Longley, C. B. Bioorg. Med. Chem. Lett. 2000, 10, 2251.

(41) McPherson, D. C.; Popham, D. L. J. Bacteriol. 2003, 185, 1423.

(42) Terrak, M.; Ghosh, T. K.; Van Heijenoort, J.; Van Beeumen, J.; Lampilas, M.; Aszodi, J.; Ayala, J. A.; Ghuysen, J.-M.; NguyenDistèche, M. Mol. Microbiol. 1999, 34, 350.

(43) van Heijenoort, Y.; Gomez, M.; Derrien, M.; Ayala, J.; van Heijenoort, J. J. Bacteriol. 1992, 174, 3549.

(44) Derouaux, A.; Turk, S.; Olrichs, N. K.; Gobec, S.; Breukink, E.; Amoroso, A.; Offant, J.; Bostock, J.; Mariner, K.; Chopra, I.; Vernet, T.; Zervosen, A.; Joris, B.; Frere, J. M.; Nguyen-Disteche, M.; Terrak, M. Biochem. Pharmacol. 2011, 81, 1098.

(45) Koppelman, C.-M.; Aarsman, M. E. G.; Postmus, J.; Pas, E.; Muijsers, A. O.; Scheffers, D.-J.; Nanninga, N.; Den Blaauwen, T. Mol. Microbiol. 2004, 51, 645.

(46) Pastoret, S.; Fraipont, C.; den Blaauwen, T.; Wolf, B.; Aarsman, M. E.; Piette, A.; Thomas, A.; Brasseur, R.; Nguyen-Disteche, M. J. Bacteriol. 2004, 186, 8370. 